\title{
SWEDISH MEDIA, FUNDAMENTAL VALUES AND THE OPINION CORRIDOR IN THE 2018 ELECTION
}

\author{
Greg SIMONS*
}

Received: 07.07.2021 - Accepted: 17.08.2021

Simons, G. (2021). Swedish media, fundamental values and the opinion corridor in the 2018 election. Etkileşim, 8, 12-34. doi: 10.32739/etkilesim.2021.4.8.136

This study complies with research and publication ethics.

\begin{abstract}
Sweden is usually ranking very highly in terms of global democracy and transparency indexes. The 2018 elections in Sweden were very divisive and bitterly fought, where there was an open conflict between the mainstream political establishment parties and the anti-political establishment Swedish Democrats. Mainstream Swedish media were not neutral bystanders in the election coverage, in the months before and after the September 2018 elections. The election coverage framing featured an idealised national myth that uses the notion of various acceptable fundamental values to define it, and an idealised Swedish society. Those actors whose values and norms that do not fit these ideals were subjected to attack and derision within a concept of consensus enforcement known as the opinion corridor, which is akin to the spiral of silence.
\end{abstract}

Keywords: framing theory, national myth, mass media, fundamental values, opinion corridor. 


\section{SEÇIMLERINDE ISVEÇ MEDYASI, TEMEL DEĞERLER VE KANAAT KORIDORU}

\section{Greg SIMONS*}

Gönderim Tarihi: 07.07.2021 - Kabul Tarihi: 17.08.2021

Simons, G. (2021). Swedish media, fundamental values and the opinion corridor in the 2018 election. Etkileşim, 8, 12-34. doi: 10.32739/etkilesim.2021.4.8.136

Bu çalışma araştırma ve yayın etiğine uygun olarak gerçekleştirilmiştir.

\section{Öz}

İsveç, küresel demokrasi ve şeffaflık endeksleri açısından çoğunlukla en üst sıralarda yer almaktadır. İsveç'teki 2018 seçimleri, ana akım siyasi partiler ile anti politik isveç Demokratları arasında açık bir çatışmanın olduğu, kutuplaştırıcı bir iklimde gerçekleşmişti. Ana akım İsveç medyası, Eylül 2018 seçimlerinden önceki ve sonraki aylarda, seçim haberlerinde objektif değillerdi. Seçime dair haberlerin çerçevesi, idealize edilmiş bir ulusal efsaneyi ve idealleştirilmiş bir ìsveç toplumunu içeriyordu. Bu ideallere uymayan değerleri ve normları olan aktörler, suskunluk sarmalına benzeyen, bir görüş birliğine zorlayan ve kanaat koridoru olarak bilinen yaklaşımla saldırı ve küçümsemeye maruz kaldılar.

Anahtar Kelimeler: çerçeveleme kuramı, ulusal mit, kitle iletişim araçları, temel değerler, kanaat koridoru.

* Doçent Doktor, Uppsala Üniversitesi, Rus ve Avrasya Çalışmaları Enstitüsü, İnsan Bilimleri Enstitüsü, Ural Federal Üniversitesi,

greg.simons@ires.uu.se, ORCID: 0000-0002-6111-5325 


\section{Introduction}

In competitive democratic environments the role and relationship between political actors and mass media outlets in attempting to define the political environment is a hotly debated topic. There are increasingly divergent projections of 'reality' evident in news production (Knupfer, 2017). This is associated with the idea of news management in shaping the content and production of news, together with how media politics contributes to the outcome of the final product (Esser and Spanier, 2005). This is not a particularly new or $21^{\text {st }}$ century problem, Bernays (1947) noted that there is no coincidence in the timing or nature of news content as it is intended to engineer political consent among the public. Some media outlets, such as Fox News, have been attributed with the capability of potentially persuading voters (Della Vigna and Kaplan, 2007). This creates the idea of an all-powerful mass media in the shape of media politics (Edwards, 2001). It is a situation where political institutions are increasingly dependent on and being shaped by mass media, yet these institutions remain in control of the political process and functions (Mazzoleni and Schulz, 1999). This mediatization of politics potentially creates a distinct challenge for the notion and practice of democracy.

This paper seeks to investigate and analyse the role and use of conceptions of national myths in the contemporary Swedish political environment. According to formal measures, Sweden ranks highly internationally in terms of its level of democracy and transparency. In this article the role of mass media outlets in perpetuating myths of fundamental national values as a means to influence and shape the information and cognitive domains and therefore election results are the focus through media framing and content. The research hypothesis posed is mainstream mass media outlets can attempt to use the myths of Swedish national value consensus to narrow the 'allowable' frame discourse in the Swedish 2018 elections.

There are three main sections of this paper. The first concerns a brief literature overview of the main arguments in terms of the practice and results of contested framing in democracies, and the connection to competitive elections. The second section outlines the method and approach used in collecting and analysing the empirical data that has been collected. The third and final section is dedicated to the case study of the 2018 Swedish elections, which is broken down in to two subsections, on the role of values and consensus in Sweden and the next subsection is on the frames of the media coverage of the election in two national newspapers.

\section{Role of Media Framing in Contemporary Competitive Politics}

Entman (2004: 5) defines framing as "selecting and highlighting some facets of events or issues and making connections among them so as to promote a particular interpretation, evaluation, and/or solution" whereas Nelson,

14 | ETKíleşim | Yıl 4|Sayı 8| Ekim 2021 
Clawson and Oxley (1997: 567) argue that "framing is the process by which a communication source, such as a news organisation, defines and constructs a political issue or public controversy". There are a number of basic functions that are performed by frames covering political events, issues and actors: "defining effects or conditions as problematic; identifying causes; conveying a moral judgement; endorsing remedies or improvements" (Entman, 2004: 5). This is important as people can learn a lot concerning politics from the mass media, Bolsen (2011: 143) argues that there are major determinants that shape political news: world events, advocacy groups and the government. Frames can perform at least two of these functions, where the objects of the frames are political events, issues and actors. As noted by Entman (2004: 47), "the central goal of all the political manoeuvring over news frames is simply to generate support or opposition to a political actor or policy". The information domain is the area of conflict and contestation for influence in the cognitive domain of the audience, where information dominance and control of the information flows shape public opinion and perception.

Being able to influence or determine news frames is important for political actors as it facilitates their political agenda (Rodelo and Muniz, 2019). In attempting to understand this government-media nexus, there are two broad approaches. The first is hegemony, which concerns the notion that government actors keep publicly available information within very tight ideological boundaries, the effect is to make democratic deliberation and influence extremely difficult. When the political elite are in agreement, then the frames are consistent, which impedes independent and pluralistic flows of information (Scollon, 2003; Kilgo and Harlow, 2019). The other approach is indexing, which occurs when media tend to reflect rather uncritically the political elite debate (unless the government has made critique). This creates an environment where government actors and officials spin their messages to gain political leverage and capital (Nelson, Clawson and Oxley, 1997; Allen and Blinder, 2018; Mulherin and Iskhan, 2019). Kilgo and Harlow (2019: 524) note that there is a tendency to reinforce the status quo power relations through a "hierarchy of social struggle reflects the reinforcement of deeper power structures and social forces that influence newsroom practices, behaviours, and coverage". The competition between different government and media actors is most noticeable during hotly contested political events or processes in competitive political environments.

A hotly contested political event can include warfare, where on occasion media outlets can violate or challenge the indexing hypothesis (Papacharissi and de Fatima Oliveira, 2008; Mulherin and Iskhan, 2019). Other instances of government-media frame divergence can include debates on sensitive political topics as immigration (Benson, 2010; Allen and Blinder, 2018). Elections and public debates (such as political scandals) have been shown to produce less balanced coverage and an increased journalistic interpretation of the event (Nelson, Clawson and Oxley, 1997; McDonald Ladd and Lenz, 2009; Hänggli, 
2020: 129-159). Thus, the academic idea and research on framing is becoming quite fragmented. Cacciatore, Scheufele and Iyengar (2016: 8) stress the idea of "framing as a bridge between paradigms as we shift from an era of mass communication to one of echo chambers, tailored information and microtargeting in the new media environment". However, the new media environment is not separated from the old environment, especially when concerning the issue of political influence and persuasion through value and myth framing.

Lewin (1947) wrote about the role of social institutions as being channels or gates for the interaction and communication of a group, the movement of goods and ideas. He argued that 'gate sections' are governed by either impartial rules or by gatekeepers. In the latter, the gatekeepers, the group in power dictates the rules. If social change occurs, then the gatekeepers also change or are influenced (1947: 145). Mass media are a gatekeeper of information, hence influence the quality of information, although the technical ability to do so in the current state of information communication technologies is compromised owing to their loss on the monopoly of the means of mass communication. Laswell (1948) understands communication as a social institution that distributes and shapes the values and norms of a society, appealing to mobilising and influencing the minds, attitudes and behaviour of its citizens. The communication process in society performs three functions: surveillance of the environment; correlation of society's components; and transmission of the social inheritance (1948: 243). McCombs (1977) developed a deeper understanding of the agenda setting function of mass media, where many attempts were noted when media campaigns attempted to persuade publics. Conventional wisdom of the time revealed that media seldom changed the attitudes and behaviour of audiences, so the notion of persuasion was unrealistic. However, McCombs noted that while media could not tell people what to think, they did tell people what to think about.

There is certainly a role for engaging in coercive or manipulative consensus building in elections, which is clearly seen through the propagation of myths in democratic settings. O'Shaughnessy (2004: 101-102) notes that myths, across time and space, possess a number of commonalities: 1) they are flexible as they can be created, refreshed or resurrected by "myth entrepreneurs"; 2) ritual homage to myths is needed in advanced democracies if political persuasion stands a chance to succeed; 3 ) myths are a key component for social cohesion, social division can arise with the collapse of a myth. Those myths that are propagated are embedded with notions of various desirable and undesirable value traits, which are then communicated through mass communicated frames to the target audience.

Myths are constituted of ideas and values, which are an important aspect of generating meaning and belonging in any given society, consequently they

16 | ETKíleşim | Yıl 4|Sayı 8| Ekim 2021 
are also framed and communicated. For example, citizens use and frame value language to explain their views on political issues, these are not only used to support political views but also to challenge them as well (Brewer, 2002). News media framing can also interact with existing value orientations where the resonance of mass mediated values with the held values in a society contributes to shaping voter preferences in direct-democratic campaigns (Schemer, Wirth and Matthes, 2012). The following section details the approach taken to addressing the above theoretical frames within the context of the coming case study.

\section{Method and Approach}

The approaches to textual analysis shall include content analysis that includes the quantifications of different elements in text, argumentation analysis that concerns the structure of argumentation used, and the qualitative analysis of ideas in the content (with a focus on value and myth frames) (Boréus and Bergström, 2017: 7-9). The combination of these approaches is expected to yield results on the ontology and epistemology of mass mediated textual depictions of the mainstream political parties' and associated values in the framing of the 2018 Swedish national elections. The objects of the study include norms and values, mainstream politics and populist politics and so forth (2017: 1-2). The mass media texts then contextualise the relationships according to perceived and projected power in the constructed social world order of mankind, such as justice and injustice, powerful and powerless, legitimate and illegitimate.

Phenomenology has been referred to as being a philosophical movement, which indicates seminal ideas evolve and do not remain static owing to the work of subsequent scholars (Lopez and Willis, 2004: 728). The empirical data shall be interpreted via the use of phenomenology, which is described as taking "human existence as its vantage point and explores how human subjects exist and create meaning in their everyday lives in relation to basic categories such as time, space and sociocultural relevance" (Bengtsson and Johansson, 2020: 6). This means that it is potentially useful to interpret news values and content, such as the relaying of national myths and values to the public. It is the intention of the author to use a qualitative approach to analyse the data to create an indicative study. A qualitative study approach to the data has been selected as this is the best means of capturing the complexity of the objects of the study (Hyett, Kenny and Dickson-Swift, 2014: 2). The empirical material shall be analysed via framing theory.

In terms of their operationalisation, frames provide the bridge between the physical world and cognitive meaning for audiences. "The key idea is that strategic actors, journalists, and audiences do not simply reflect or transport the political and social realities. In contrast, politics, issues, and events are 
subject to different patterns of selections and interpretations" (Matthes, 2012:249). Qualitative textual analysis is often done on a small sample of text, which is heavily interpreted and deeply investigated to identify and justify the frames used in the media discourse surrounding the issue (David et al, 2011: 331). The approach to locating and analysing the frames can take different paths, such as an inductive mixed-method computational approach, which still requires a qualitative interpretation of the data collected (Walter and Ophir, 2019). Another option is to engage in a deductive study using a quantitative approach (Dirikx and Gelders, 2010). This study intends to engage in deductive research agenda with a qualitative analysis. The approach to selecting the Swedish newspapers is detailed below.

It is necessary to briefly introduce some basic facts and figures concerning the two newspapers selected for this case study to understand the possible editorial influences and impact. Expressen is a newspaper that was established in 1944 and is part of the Bonnier News Group, they classify themselves as being a "classic evening newspaper" with a liberal orientation, and a recent readership of 5.000 .000 readers per week (49.4 per cent of the market). ${ }^{1}$ Aftonbladet was founded in 1830 and describe themselves as being editorially "independent Social Democratic." It is currently majority owned (91 per cent) by the Norwegian Media Group Shibsted (other nine per cent by the national union LO). ${ }^{2}$ In September 2019, Aftonbladet had a daily circulation of 3.7 million readers (Samuelsson, 2 September 2019). These two newspapers represent each other's main competitor in the Swedish newspaper market.

These newspapers were chosen because they represent a similar comparative case study of mainstream tabloid media outlets with a national coverage, albeit with different ideological slants (right versus left politics). Furthermore, these media outlets are selected based on their potential of the intention and/or ability to reach large mass publics as opposed to outlets intending to reach smaller and more select elite publics. The materials were sought and collected on the websites of the Swedish tabloid newspapers Expressen and Aftonbladet through manual searches. A period was selected for the materials, which starts at the beginning of June 2018 and ends in the end of December 2018. This represents a period of three months coverage before the September 2018 election and three months after the election. The author of the present article translated the newspaper texts from Swedish language into English language in the course of researching and writing.

\section{Case Study: 2018 Swedish General Election}

\section{The politics of media, values and opinions in Sweden}

Political (emphasis on elections) and media systems have been the basis for

\footnotetext{
${ }^{1}$ To see more (in Swedish): go to: (Expressen, 2017).

${ }^{2}$ To see more (in Swedish) go to: (Aftonbladet, 2020).
}

18 | ETKíleşim | Yıl 4|Sayı 8|Ekim 2021 
research to tease out the national differences and similarities across national cases. The Swedish system has been compared to other countries, such as the United States (representing dissimilar comparative case) and Belgium (representing similar comparative case). In the US versus Swedish comparisons, it was found that US elections tended to be more heavily mediatized than in Sweden, which seems to have been moderated by national journalism cultures, political communication cultures and political news cultures (Strömbäck and Dimitrova, 2011). In a comparative study of newspaper coverage and framing of election news in the US and Sweden, it was concluded that the metaframe of politics as a strategic game influenced by words and actions in the campaign was more common in the US whereas the metaframe of politics as issues using an interpretative journalistic style was more common in Sweden (Strömbäck and Dimitrova, 2006). Similar results were found in research that compared British and Swedish newspaper coverage of elections (Strömbäck and Shehata, 2007). The study involving a comparison between Belgium and Sweden demonstrated the relevance and role of the media type, media channels and commercialisation as being very important in influencing the framing and approach to election news in more similar media environments (Strömbäck and van Aelst, 2010). Hence some specific trends and patterns emerge in the Swedish political and media environment, where interpretive issue framing plays a significant role in Swedish media coverage of elections. Nord (2006) notes that Sweden is being increasingly influenced by global campaign and marketing trends, which is somewhat stinted in its development owing to the nature of political culture in Sweden.

Previous research on the communication of elections in Sweden has revealed a number of aspects, which show both similarities and differences with other democracies. For example, the use of social media during election campaigning revealed four different uses: 1 ) broadcast election messages; 2 ) mobilize supporters; 3 ) manage party image; and 4) amplify and complement other campaign material (Filimonov et al, 2016; Larsson, 2017). It was during the 2014 elections that the Swedish Democrats (SD) ("populist" party) increased their share of the vote from 5.7 per cent in 2010 to 12.86 per cent in 2014 (Filimonov et al, 2016: 4). Social media are a fraction of the media of communication, which calls in to focus the nature of the relationship between politicians and journalists.

Strömbäck and Nord (2006) explain that this relationship between political sources and journalists is often characterised as being a symbiotic one, where political sources are regarded as being more powerful. In their investigation of the 2002 election, where power is measured in the ability to exercise control over content and framing of news stories (news making and media agenda), journalists took the lead most of the time. This is confirmed by other older studies, such as Esaiasson (1991) and Asp (1983) who assessed political parties controlled agenda setting and opinion formation for the voters until the end of the 1960 s when a more assertive form of political journalism emerged. This 
is where the formation and maintenance of public opinion is achieved through the creation and enforcement of national values.

The role of fundamental values (in Swedish värdegrund) and the opinion corridor (in Swedish åsiktskorridor) display some similarity to O'Shaughnessy's (2004) ideas on the role of propagating myths in a democratic society. The Swedish national values myth is rather inflexible and is enforced through the opinion corridor in a manner that bears a close proximity to the spiral of silence theory where 'officially acceptable' opinions are openly supported and 'unacceptable' ones are hushed/silenced (Noelle-Neumann, 1974). These values follow Baines and O'Shaughnessy's (2014) understanding of a propagandistic use insofar as they are - simple, didactic and intended to persuade rather than tell the truth. This is in tune with Bolsen's (2004) understanding of forces that shape political news and that in turn political events, issues and actors in a manner that benefits the elite system of power relations. Swedish values require ritual homage in order to enforce social cohesion.

In 2014 åsiktskorridor was added to the new word list (Jande, 29 December 2014). This has sparked a growing debate in Sweden concerning the role played by values and opinion in shaping (enforcing) political consensus through the hegemonic framing power of the opinion corridor in narrowing crucial political debates within "acceptable" value and issue frames and limits (Viklund, 2015; Santesson, 14 September 2015). Recently, a number of critical articles have increasingly appeared to challenge the opinion corridor. Some have characterised this as a challenge for researchers, and the problem is a threat to Sweden by stifling informed discussions (Petersson, November 2015). One of the bases for attacking the opinion corridor is the apparent contradiction with the perceived values of democracy. "In ceremonial speeches, democracy is still based on values such as freedom of opinion, freedom of expression and tolerance for directly offensive perceptions" (Formgren, 2014). Formgren develops her argument further and refers to these self-appointed guardians of democracy as being Fundamental Values Democrats, they practice the belief that unwanted or unsanctioned opinions need to be shut out of the public domain in order to secure democracy. Those as yet undefined fundamental values are a patchwork of loosely liberal values and norms that are cobbled together in terms of opinions that are sanctioned as being correct.

Anti-racism, feminism and queer activism are key elements in both the post-Marxist left and the Swedish democratic values. If you add a concern for the environment that is similar to religious fear of the world's downfall, as well as the norm-critical paradigm that proclaims that all old norms, values and authorities must be torn down and deconstructed, the picture is complete. The Swedish democratic values are thus almost identical to the ideology of the Swedish post-Marxist left, minus specific views on how economic policy should be formulated (Formgren, 2014).

One of the vocal critics against the opinion corridor, Katarina Barrling, refers to the situation as the creation of a "totalitarian discussion environment" as 
there are value judgements against those that do not echo the above 'correct' values and opinions. "Moral judgments of rejection and exclusion from a social community can be quite tangible punishments" (Barrling, 28 June 2019). Viklund (2015: 228) observes that "the problem is that the hegemonic culture strictly produces only two positions: on the one hand the support position, which rests on a moral-political consensus, and which is supported by arguments about what is common sense, and on the other hand the "others" who represent an immoral position." Barrling makes the case that media deliberately misinterpret events and people to ensure that these tangible objects are misunderstood objectively but understood 'correctly' subjectively and according to the sets of fundamental values deemed as being acceptable (Barrling, 11 November 2013). This has been subsequently confirmed in an editorial appearing in the newspaper Expressen:

I was involved in building the corridor that has prevented a constructive debate on migration and integration. (...) At the same time, SD began to appear on the map. Just the idea that Sweden could have such a disgusting party in the Riksdag was unbearable. And in addition, insulting. Sweden was Sweden, the exceptional exception, the humanitarian superpower. (...) The assignment for me as a corridor worker was twofold. First, to warn the SD and scold all those beggars who considered voting for the party. Secondly, to crack down on debaters who used expressions that could somehow normalize SD's problem description; attack every bastard who used words or facts that could in any way be interpreted as racism or slips against racism. Or possible precursors to slips against racism. (Marteus, 12 February 2015).

The conclusion that Marteus reached was that the opinion corridor prevented any change in fundamental values, however, the price was very high. It was paid in self-censorship, an uninformed public, overly 'excited' politicians and societal problems were left unaddressed as they were not discussed. In the period immediately before the 2018 (September) Swedish elections, the top political issues for a sample of Swedish voters were healthcare, followed by mass migration/integration, then school and education (Novus, June 2020). As such, there is a clear potential challenge to the 'correct' fundamental values and the issues of how to manage this in the opinion corridor during a period of increased political competition.

\section{National media coverage of political frames, values and norms}

Relevant editorials, opinion pieces and articles were located, identified, and then scrutinised from the respective websites of the two newspapers using the following search terms - "valet" (the election). To acknowledge, opinion pieces vary qualitatively from regular articles produced by professional journalists, but it is the conscious and free choice of the media outlet to publish or not to publish an opinion piece. A total of 614 were collected from Expressen and 1067 from Aftonbladet. See Table One below for a breakdown of the article totals by month. These articles were checked individually by manual means to 
check the relevance of the article to this paper and to understand the myth, opinion and value frames that are used in the media product.

As can be seen by this breakdown, there is a significant spike in the number of articles in the month before the election and the month of the election (election held on 9 September 2018) in the content of both newspapers. The use of Swedish fundamental values and the opinion corridor (see previous sub-section for details) was used differently, depending on the time of appearance, which supported the myth of fundamental Swedish values. Before the election the framing of the content was used to persuade voters to support the mainstream political establishment against various frames of internal and external 'threats.' After the election result of a hung parliament, the purpose of framed content was to marginalise the Swedish Democrats from political power, based upon notions of fundamental values and enforced through the opinion corridor. The various recurring frame themes in both newspapers included: internal enemies (in political value ideological terms); external enemies (in geopolitical value ideological terms); political market offerings (campaign promises by parties and politicians); opinion polls (shape voter perception of winners and losers); issues for voters (hegemonic framing); and key political actors (in terms of values and opinions).

Table 1. Newspaper Swedish Election articles per month

\begin{tabular}{|c|c|c|c|c|c|c|c|c|}
\hline & 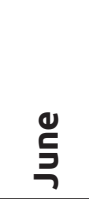 & 곡 & 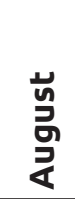 & 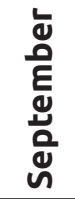 & $\begin{array}{l}\text { ப் } \\
\stackrel{0}{0} \\
\stackrel{\circ}{u} \\
\text { o }\end{array}$ & 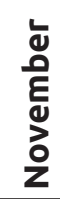 & 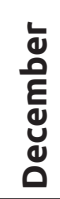 & $\begin{array}{l}\text { गु } \\
\text { 。 }\end{array}$ \\
\hline Aftonbladet & 113 & 79 & 181 & 470 & 89 & 75 & 60 & 1067 \\
\hline Expressen & 47 & 33 & 183 & 299 & 25 & 13 & 14 & 614 \\
\hline
\end{tabular}

Articles appearing in Aftonbladet shall be the first to be reviewed in terms of how the paper sought to make use of the propagation of myth and features of opinions and values in politics. In the frame that makes use of opinion polls, the dire situation of the lead Government coalition party, the Social Democrats is laid out 100 days before the election. The situation is characterised as a "nightmare" for Prime Minister Stefan Löfven. There is also an element of an internal threat frame. "But one fact will stand. The Sweden Democrats continue as wave leaders between blue and red-green, albeit significantly larger than after the last election" (Mellen, 1 June 2018). The threat to the Social Democrats and its leader, and the threat of the Swedish Democrats and its leader feature as the main 'lessons' of the article. The "crisis" of the Social Democrats features in several articles in the first months of the period of study. One of the reasons given for the poor performance of the Social Democrats is that there are too many policy proposals (but saying more

22 | ETKíleşim | Yıl 4|Sayı 8| Ekim 2021 
needed on medical care and schools), "one thinks that there have been too many initiatives, another thinks that there is too much talk about migration" (Jeppsson and Svensson, 1 June 2018). There is an attempt at hegemonic framing to shift focus towards the acceptable fundamental values and away from those values that contradict them.

In a frame on politicians and parties, there is an article that criticises Swedish parties and seeks to find inspiration, in terms of marketing a personal political brand and reputation. A template for a desirable political brand is found in the French President Macron, and the call for a Swedish Macron to appear in the political market (Mellen, 3 June 2018):

How would you like to characterize the political situation in Sweden today? I would say that overall, even if there are exceptions, it is uninspiring, unimaginative and visionless. This despite eight parties in the Riksdag [Swedish Parliament] that could inspire each other. But which at the moment rather seem to lead to them paralyzing each other. (...) It can happen here too. Or rather, it will happen here as well. The conditions are the same. Tired old parties that are unable to detach from old structures that prevent them from developing. Combined with voters who are thirsty for something new, something exciting, someone who shows will and enthusiasm.

This is a call to revitalise the political establishment parties, which is deemed as being necessary to meet the rising anti-political establishment parties (namely Swedish Democrats). Despite criticism levelled at the establishment parties, a journalist promoted her opinion that these are the best option. "But that would deprive the Sweden Democrats of any form of influence. Even the indirect. My belief is that the best thing for Sweden after the election is a government that consists of either the Social Democrats or the Moderates" (Mellen, 17 June 2018). This is an instance of encouraging readers to vote for the mainstream political establishment parties. Where Swedish Democrats are characterised as being extremists (with Nazi connotations), any politician that seeks cooperation with SD and any voter that supports them is demanded to provide an explanation for their actions and thoughts. (Swedin, 21 June 2018). Other politicians that are ambiguous in their condemnation of SD are commanded to publicly display their loyalty to the fundamental values and the opinion corridor (Lövin, 29 June 2018). The anti-SD messages intensified in quantity with the approaching election day. These measures to enforce the opinion corridor are supplemented by suggestions of connections to foreign 'threats' (Lindberg, 15 August 2018).

In line with other global moral panics that are created around elections (Simons, 2019), Sweden attempts to project the 'other' (these can include Russia, China and Iran according to various articles) hostile foreign threat to the Swedish political and social system, together with its values (TT, 4 June 2018):

We know that advocacy campaigns are underway and Russia is the biggest threat, says Löfven (S) after the meeting. However, he believes that Swedish authorities 
are "very well prepared". If there is an advocacy campaign, we will not hesitate to release those who do this. He urges citizens to be critical of sources. Based on the knowledge we have from other elections such as the French and the American, we must assume that we will not be protected, says Löfven in answer to the question of how big the threat is.

The foreign threat is simultaneously 'menacing' and yet rather vague. This is an attempt to get the voters to rally around the flag of the mainstream political establishment parties at a time when they were in serious trouble in the polls leading up to the election.

Political policy offers were often framed within competing visions of voter issues, policy priorities and fundamental values, tinged with character attack:

Prime Minister Stefan Löfven launched a fierce attack on Jimmie Åkesson. You should google the word "humanism", Löfven told the SD leader. Åkesson replied: The Prime Minister has failed with welfare because he prioritized asylum immigration. SD leader Jimmie Åkesson accused the government of spending the money on asylum immigration instead of cutting care queues and improving for the elderly. I boil down Stefan Löfven's time as Prime Minister to one word: disaster. Åkesson took up healthcare initiatives and initiatives to stop crime.

These are incompatible value frames, one that follows the opinion corridor and the other that contravenes it. The result of the election, which the Government coalition lose a lot of mass support, and SD increase its popular support significantly and this is reflected upon a lot in the articles appearing in September 2018.

After the election attention turned to issues, such as the record number of complaints and cases filed against election 'irregularities' (TT, 15 September 2018), and pondering on building a new government coalition without SD.

The Speakers are Sweden's main representatives and shall represent the Swedish Parliament in national and international contexts. To elect a Sweden Democrat to a chairmanship is to give legitimacy to their views. It is completely unacceptable that a country like Sweden, which claims to stand for human rights, should allow itself to be represented by a racist (Dinamarca, 18 September 2018).

Once more, the myth of Sweden's fundamental values are contrasted with a set of contrasting values that would 'shame' Sweden nationally and internationally. As with the previous examples, the logic is emotional, didactic in nature and the main aim is persuasion of the mass audience and not to inform them. There are also attempts to try and minimize the scale of the government's humiliating defeat in the 2018 election, by trying to frame them as having a comeback after one month (although 29.7 per cent is hardly a good result) (Aftonbladet, 9 October 2018). The deadlock that almost triggered a new election, the prospect is dismissed as only pleasing and pandering to Sweden's internal 'enemies' (Lindberg, 21 October 2018). On a final note on Aftonbladet's frames, there were numerous articles from October 2018 on the issue of trying to push a compromise to form a Red-Green party alliance

24 | ETKíleşim | Yıl 4 |Sayı 8| Ekim 2021 
in order to prevent a conservative or right-wing influenced government from forming (Mellen, 10 December 2018). In general, and in keeping with previous research, Aftonbladet led the hegemonic framing process. Political parties and actors were able to get their messages in, only if those messages coincided with the media outlet's imperatives in the news frames at the time. The necessities were determined by the nature of the social and political struggle being communicated to the readers to support the status quo in maintaining the national myth of Swedish fundamental values.

Now moving to analysing the same set of news frames for the data sample from the newspaper Expressen. As with Aftonbladet, Expressen began in June with articles concerning the looming election crisis for the Social Democrats 100 days before the scheduled Election Day, featuring the frames of opinion polls, voter issues and political market offerings. This was characterised as being an "opinion crisis." The Prime Minister was quoted as to the way forward:

We have discussed what the way forward towards election win should look like. We are fully committed to ensuring that people get to work, that there are decent conditions in the labour market, safe working conditions that the school should work for the children, that healthcare works, that care for the elderly is good.

There were also emotional slogans, which defied the perceived reality in the electorate. "We will continue to invest in the proposals that make Sweden stronger" (Nilsson and Rogvall, 1 June 2018). There is no mention of the immigration crisis at all, which is a key voter issue, but one that contravenes the fundamental values concept. One Swedish journalist went as far as to openly state the likely election 'catastrophe' that was shaping for the ruling government and not to try and minimise the possible impact and repercussions (Bergström, 5 June 2018).

In the months before the election, many of the informational materials concerned the frames of political market offerings, voter issues, opinion polls and key political actors. The positioning and games of key political actors were also followed, and possible power struggles detailed, for example suggesting that Christian Democrat politicians wanting to see a new party leader after poor opinion polls (Skoglund, 5 June 2018). Space was also devoted to creating negative analogies between President Trump (foreign enemy) and the Swedish Democrats (internal enemy):

There is a general feeling in many groups in society that one has an exclusion. This was also noticed in the US presidential election, where Trump managed to ride on such a wave. He was a saviour who understood ordinary people. The same can be seen in how the Sweden Democrats are perceived by us (Andersson et al, 10 June 2018).

This came at the point in time when the SD party was announced as the most popular party according to opinion polls. The taboo of political parties and politicians contemplating cooperation with SD was also covered (Skoglund, 14 June 2018): 
In Wednesday's episode of "Bara politik" (Only Politics), the Moderate Member of Parliament Hanif Bali opened up for a collaboration with SD on certain issues, including migration policy. "I am a person who is not so terrified that if I talk to a Sweden Democrat, I will end up becoming a fascist. I will not become a farmer because I talk to a centre-right party member.

This was predictably severely condemned by mainstream politicians and journalists using value ideological judgements. Such acts that defy the fundamental values myth are referred to as being political games and acts of betrayal.

Different political parties and politicians are seen to be positioning themselves in the political market prior to the election, which is done through competing political policy offerings to the political policy consumers (the voters). This is done within limits, and a number of the parties do not want to touch the political sensitive (because of the fundamental values), but highranking voter concern of the immigration issue, which is also linked to other important voter concerns as law and order. This can be seen in the nature of the competition and challenges made by political parties and politicians to one another. For example, the challenge by Christian Democrats (Busch, 4 August 2018):

In his summer speech, the Christian Democrats' party leader Ebba Busch Thor challenged Prime Minister Stefan Löfven (Social Democrats) to make the election a referendum on welfare. She wants to prioritize childcare, healthcare and care for the elderly and make it easier for women to combine work with leisure.

An interesting lesson noted in one article was that opinion polls were kinder to politicians and parties that aligned their political offers more closely with key voter concerns, even if it ran contrary to the fundamental values concept (Cardell, 4 September 2018). Unlike Aftonbladet, a number of political leaders were able to publish opinion pieces in Expressen in order to reach the voters with their uninterrupted message.

There were also articles featuring the topic frame of foreign enemies. Stefan Löfven was quoted that "there is nothing to say that future Swedish elections will be protected. On the contrary, today we see clear signs of advocacy operations aimed at Sweden" (Löfven, 4 June 2018). This is also in line with the quality of the content in Aftonbladet. Various vague and alarming statements are made, which lack the necessary concrete proof. "Russia is investing heavily in influencing the decision-making process in countries like Sweden - and is focusing on the election next month" (Lapidus, 9 August 2018).

The post-election coverage proved to demonstrate remarkable similarities to the coverage by Aftonbladet. The main points being to keep SD from gaining political power because of political-ideological values and the condemnation of those that cooperate (Kinnaman, 28 October 2018), intrigues and games to take political power (Lööf, 30 October 2018), the risks of an extra election giving more influence to SD (Baas, 1 December 2018), and the call to form 
a government after 100 days since the election (Expressen, 17 December 2018). Expressen tended to be less didactic in the quality and approach to its reporting, it was still instructive and value judgmental within the context of the fundamental values and made use of the opinion corridor.

\section{Conclusion}

In the introduction to this article, the research hypothesis posed is mainstream mass media outlets can attempt to use the myths of Swedish national value consensus to narrow the 'allowable' frame discourse in the Swedish 2018 elections. The findings indicate that the hypothesis is supported as there is a strong use of projecting an idealised national myth of Sweden in terms of the values and opinions that constitute the meaning and identity of contemporary Swedish society. In several previous international studies (Scollon, 2003; Kilgo and Harlow, 2019), it is the political actors that tend to play the leading role in hegemonic framing. However, this study hints at confirming some existing research on Sweden's exceptional case of media taking the lead (Asp, 1983; Esaiasson, 1991). The media outlets observed also tended to follow the frame pattern elaborated by Entman (2004) on defining conditions as being problematic, identifying causes, conveying moral judgement and endorsing remedies. These Swedish media outlets were acting in the capacity of an advocate for an idealised myth of Swedish values and opinions as a means for generating national consensus on a political system undergoing opinion and value change. This fits with Bolsen (2011) and Entman's (2004) understanding of the role played by frames in politics.

There was heavy use made of emotions, on one end of the emotional scale was fear and loathing to drive the audience away voters from supporting politicians or political parties that were identified as having the 'wrong' fundamental values. On the other end of the emotional scale was the use of pride and hope to push voters towards those politicians and political parties that were identified as having the 'correct' fundamental values. This use constitutes the involvement of framing propaganda, meeting Baines and O'Shaughnessy's (2014) markers of being simplistic, didactic and persuasive (as opposed to truthful). It was used to defend, in its moment of need, the notion of Swedish fundamental values (within the context of them being understood as a myth) that are used as a means of enforcing social and political cohesion. This is noticeable through understanding the workings of the Swedish opinion corridor, which resembles in some ways the idea of the spiral of silence owing to the process of hegemonic framing of 'correct' values and opinions and to exclude others that do not conform. These are essential tools for selecting and highlighting specific facets that are intended to generate continued support of the hegemony of the current social hierarchy. 
A final note is that the effectiveness of the opinion corridor as a mechanism to guard and uphold the existing social hierarchy in Sweden with its reliance on the myth of common fundamental values to enforce social and opinion cohesion is beginning to fail. Journalists and the media outlets in this study have proven to be almost messianic in their quest to maintain the social hierarchy's status quo. Journalists and media outlets have actively sought to uphold their idealised vision of "democracy" that is visualised by the myth of the fundamental values by policing the opinion corridor, even when this creates costs and contradictions. It is evident the cracks in the opinion corridor are appearing more openly now with (relatively speaking) more open discussions occurring in public spaces.

Some limitations need to be noted in this study. Firstly, it should be noted that two Swedish tabloid newspapers have been chosen for the study, which necessitates adding that as a limitation on the study. As broadsheet and tabloids newspapers have been shown to have a different qualitative result in the motivations and editorial line of their news and information products. Tabloid journalists act in the capacity as a public mobilizer, which is related to a personalization (Skovsgaard, 2014). Secondly, these are only two tabloid newspapers in a much larger Swedish media market, therefore this is an indicative study only.

\section{References}

Aftonbladet (9 October 2018). Socialdemokraterna går starkt framåt - en månad efter valet. https://www.aftonbladet.se/nyheter/samhalle/a/EoMdwK/ socialdemokraterna-gar-starkt-framat--en-manad-efter-valet. 23 July 2020.

(2 September 2020). Om Aftonbladet. https://www.aftonbladet.se/ omaftonbladet/a/LOlQ4/om-aftonbladet.

Allen, W. L. and Blinder, S. (2018). Media independence through routine pressstate relations: Immigration and government statistics in the British press. The International Journal of Press/Politics, 23(2), 202-226.

Andersson, A., Bråstedt, M., Hellberg, M. and Rogvall, F. (10 June 2018). S och M backar - SD nu näst störst. Expressen. https://www.expressen.se/nyheter/val2018/-s-och-m-backar-sd-nu-nast-storst/. 24 July 2020.

Asp, K. (July 1983). The struggle for the agenda: Party agenda, media agenda, and voter agenda in the 1979 Swedish Election Campaign. Communication Research, 10(3). 333-355.

Baas, D. (1 December 2018). Akesson: Bara SD som skulle vinna på extraval. Expressen. https://www.expressen.se/nyheter/strax-akesson-talar-pa-sds-kommundagar/. 24 July 2020.

28 | ETKíleşim | Yıl 4|Sayı 8| Ekim 2021 
Baines, P. R. and O'Shaughnessy, N. J. (2014), Political marketing and propaganda: Uses, abuses, misuses. Journal of Political Marketing, 13(1-2), 1-18.

Barrling, K. (11 November 2013). Ohederliga debattekniker kortsluter debatt. DT. https://www.dt.se/artikel/ohederliga-debattekniker-kortsluter-debatt. 21 July 2020.

Bengtsson, S. and Johansson, S. (2020). A phenomenology of news: Understanding news in a digital culture. Journalism. doi: 10/1177/1464884919901194.

Benson, R. (2010), What makes for a critical press? A case study of French and U.S. immigration news coverage. The International Journal of Press/Politics, 15(1), 3-24.

Bergström, K-G. (5 June 2018). S kan få sitt sämsta valresultat någonsin. Expressen. https://www.expressen.se/kronikorer/k-g-bergstrom/s-kan-fa-sitt-samstavalresultat-nagonsin/. 24 July 2020.

Bernays, E. L. (1947). The Engineering of consent. The ANNALS of the American Academy of Political and Social Science, 250, 113-120.

Bolsen, T. (2011). The construction of news: Energy crises, advocacy messages, and frames towards conversation. International Journal of Press/Politics, 16(2), 143162.

Boréus, K. and Bergström, G. (2017). Analysing text and discourse: Eight approaches for the social sciences. Thousand Oaks (CA): Sage Publishing.

Brewer, P. R. (2002). Framing, value words, and citizens' explanations of their issue opinions. Political Communication, 19(3), 303-316.

Busch, E. (4 August 2018). Busch Thors utmaning till Löfven inför valet. Expressen. https://www.expressen.se/nyheter/val-2018/busch-thors-utmaning-till-lofveninfor-valet/. 24 July 2020.

Cacciatore, M. A., Scheufele, D. A. and lyengar, S. (2016). The end of framing as we know it ... and the future of media effects. Mass Communication and Society, 19(1). 7-23.

Cardell, J. (4 September 2018). Ebba Busch Thors förtroende ökar. Expressen. https://www.expressen.se/nyheter/val-2018/ebba-busch-thors-fortroendeokar-/. 24 July 2020.

David, C. C., Atun, J. M., Fille, E. and Monterola, C. (2011). Finding frames: Comparing two methods of frame analysis. Communication Methods and Measures, 5(4), 329-351.

Della Vigna, S. and Kaplan, E. (2007). The fox news effect: Media bias and voting. The Quarterly Journal of Economics, 122(3), 1187-1234.

Dinamarca, R. (18 September 2018). En talman från SD är en skam för Sverige. Aftonbladet. https://www.aftonbladet.se/debatt/a/VR8and/en-talman-fran-sdar-en-skam-for-sverige. 23 July 2020. 
Dirikx, A. and Gelders, D. (2010). To frame is to explain: A deductive frame-analysis of Dutch and French climate change coverage during the annual UN conferences of the parties. Public Understanding of Science, 19(6), 732-742.

Edwards, L. (2001). Media politik: How the mass media have transformed world politics. Washington DC: The Catholic University of America Press.

Entman, R. M. (2004). Projections of power: Framing news, public opinion, and U.S. foreign policy. Chicago: University of Chicago Press.

Esaiasson, P. (September 1991). 120 years of Swedish Election campaigns: A story of the rise and decline of political parties and the emergence of the mass media as power brokers. Scandinavian Political Studies, 14(3), 261-278.

Esser, F. and Spanier, B. (2005). News management as news: How media politics leads to metacoverage. Journal of Political Marketing, 4(4), 27-57.

Expressen (18 September 2017). Välkommen till Expressen. https://www.expressen. se/om-expressen/valkommen-till-expressen/.

(17 December 2018). 100 dagar sen valet-vad har hänt hittills?. Expressen. https://www.expressen.se/tv/politik/100-dagar-sen-valet---vad-har-hanthittills/. 24 July 2020.

Filimonov, K., Russmann, U. and Svensson, J. (July-September 2016). Picturing the party: Instagram and party campaigning in the 2014 Swedish Elections. Social Media + Society, 1-11. doi: 10.1177/2056305116662179.

Formgren, M. (2014). Demokrater för Åsiktsfrihet, och Demokrater Emot. Neo Magazine. http://magasinetneo.se/artiklar/demokrater-for-asiktsfrihet-ochdemokrater-emot/.4. 21 July 2020.

Hänggli, R. (2020). Origin of dialogue in the news media. Cham (Switzerland): Palgrave MacMillan.

Hyett, N., Kenny, A. and Dickson-Swift, V. (2014). Methodology or method? A critical review of qualitative case study reports. International Journal of Qualitative Studies on Health and Well-being, 9(1). doi: 10.3402/qhw.v9.23606.

Jande, P. A. (29 December 2014). Från attefallhus till åsiktskorridor. Institutet för Språk och Folkminnen. http://www.isof.se/om-oss/nyheter-och-press/ nyhetsarkiv/nyheter-2014/2014-12-29-fran-attefallshus-till-asiktskorridor.html. 20 July 2020.

Jeppsson, J. and Svensson, O. (1 June 2018). Intern kritik mot s-ledningen: För många utspel. Aftonbladet. https://www.aftonbladet.se/nyheter/samhalle/a/ Eo9AKl/intern-kritik-mot-s-ledningen-for-manga-utspel. 23 July 2020.

Kilgo, D. K. and Harlow, S. (2019). Protests, media coverage, and a hierarchy of social struggle. The International Journal of Press/Politics, 24(4), 508-530.

Kinnaman, J., (28 October 2018). Håll gränsen, Kristersson - SD måste stängas ute. Expressen. https://www.expressen.se/debatt/hall-gransen-kristersson-sdmaste-stangas-ute/. 24 July 2020.

30 | ETKíteşim | Yıl 4 |Sayı 8| Ekim 2021 
Knupfer, C. B. (2017). Diverging projections of reality. Journalism Studies. doi: 10.1080/1461670X.2017.1387072.

Lapidus, A. (9 August 2018). Underrättelsechefen: Ryssland försöker påverka svenska valet. Expressen. https://www.expressen.se/nyheter/val-2018/underrattelsechefen-ryssland-forsoker-paverka-svenska-valet/. 24 July 2020.

Larson, A. O. (2017). Going viral? Comparing parties on social media during the 2014 Swedish Election. Convergence: The International Journal of Research into New Media Technologies, 23(2), 117-131.

Lasswell, H. D. (1948). The structure and function of communication in society. L. Bryson (ed.) The Communication of Ideas, New York: The Institute for Religious and Social Studies, 202-243.

Lewin, K. (1947). Frontiers in group dynamics II: Channels of group life; social planning and action research. Human Relations, 1(2), 143-153.

Lindberg, A. (15 August 2018). "En var som röstar på SD röstar för Moskva". Aftonbladet. https://www.aftonbladet.se/ledare/a/XwQOXx/en-var-som-rostarpa-sd-rostar-for-moskva. 23 July 2020.

(21 October 2018). Jimmie Åkesson kan skratta hela vägen till nyvalet. Aftonbladet. https://www.aftonbladet.se/ledare/a/0Ed9k6/jimmie-akessonkan-skratta-hela-vagen-till-nyvalet. 23 July 2020.

Lopez, K. A. and Willis, D. G. (2004). Descriptive versus interpretive phenomenology: Their Contribution to nursing knowledge. Qualitative Health Research, 14(5), 726-735.

Löfven, S. (4 June 2018). Löfven pratar valpåverkan med de andra partiledarna. Expressen. https://www.expressen.se/nyheter/val-2018/lofven-pratar-valpaverkan-med-de-andra-partiledarna/. 24 July 2020.

Lööf, A. (30 October 2018). Lösningen är enkel: Lööf blir statsminister. Expressen. https://www.expressen.se/debatt/losningen-ar-enkel-annie-loof-ska-regera/. 24 July 2020.

Lövin, I. (29 June 2018). Lööf måste välja om hon är för eller mot SD. Aftonbladet. https://www.aftonbladet.se/debatt/a/oRGxyw/loof-maste-valja-om-hon-ar-foreller-mot-sd. 23 July 2020.

Marteus, A. C. (12 February 2015). Det är Jag Som är Åsiktskorridoren. Expressen. https://www.expressen.se/ledare/ann-charlotte-marteus/det-ar-jag-som-arasiktskorridoren/. 21 July 2020.

Matthes, J. (2012). Framing politics: An integrative approach. American Behavioural Scientist, 56(3), 247-259.

Mazzoleni, G. and Schulz, W. (1999). "Mediatization" of politics: A challenge for democracy?. Political Communication, 16(3), 247-261.

McCombs, M. (1977). Agenda setting function of mass media. Public Relations Review, 3(4), 89-95. 
McDonald Ladd, J. and Lenz, G. S. (2009), Exploiting a rare communication shift to document the persuasive power of the news media. American Journal of Political Science, 53(2), 394-410.

Mellen, L. (1 June 2018). En Mardröm för Löfven. Aftonbladet. https://www. aftonbladet.se/nyheter/kolumnister/a/1kGbzQ/en-mardrom-for-lofven. 23 July 2020.

(3 June 2018). Vi kan få en egen Macron - frågan är bara när. Aftonbladet. https://www.aftonbladet.se/nyheter/kolumnister/a/vmPpvm/vikan-fa-en-egen-macron--fragan-ar-bara-nar. 23 July 2020.

(17 June 2018). Det bästa vore en regering med bara S eller M. Aftonbladet. https://www.aftonbladet.se/nyheter/kolumnister/a/8wK29W/detbasta-vore-en-regering-med-bara-s-eller-m. 23 July 2020.

(10 December 2018). Nu är det nog - fixa en regering och det snabbt. Aftonbladet. https://www.aftonbladet.se/nyheter/kolumnister/a/EoPW35/nuar-det-nog--fixa-en-regering-och-det-snabbt. 23 July 2020.

Mulherin, P. E. and Isakhan, B. (2019). State-media consensus on going to war? Australian newspapers, political elites, and fighting the Islamic state. The International Journal of Press/Politics, 24(4), 531-550.

Nelson, T. E., Clawson, R. A. and Oxley, Z. M. (September 1997), Media framing of a civil liberties conflict and its effect on tolerance. The American Political Science Review, 91(3), 567-583.

Nilsson, M. and Rogvall, F. (1 June 2018). "Opinionskris för S: Vi har 100 dagar på oss". Expressen. https://www.expressen.se/nyheter/val-2018/opinionskris-for-spartistyrelsen-mots-/. 24 July 2020.

Noelle-Neumann, E. (June 1974). The spiral of silence a theory of public opinion. Journal of Communication, 24(2), 43-51.

Nord, L. W. (2006). Still the middle way: A Study of political communication practices in Swedish Election campaigns, Journal of Press/Politics, 11(1), 64-76.

Novus (June 2020). Juni 2020: Sjukvård fortsatt viktigaste politiska frågan. https:// novus.se/valjaropinionen/valjarforstaelse/viktigaste-politiska-fragan/. 21 July 2020.

O'Shaughnessy, N. J. (2004). Persuasion, myth and propaganda. Journal of Political Marketing, 3(3), 87-103.

Papacharissi, Z. and de Fatima Oliveira, M. (2008). News frames of terrorism: A comparative analysis of frames employed in terrorism coverage in U.S. and U.K. newspapers. Press/Politics, 13(1), 52-74.

Petersson, G. (November 2015). Motbilder för Hållbar Mångfald: Livriktning Hotar Sverige. https://core.ac.uk/download/pdf/70614237.pdf. 20 July 2020.

32 | ETKíteşim | Yıl 4 |Sayı 8| Ekim 2021 
Rodelo, F. V. and Muniz, C. (2019). Government frames and their influence on news framing: An analysis of cross-lagged correlations in the Mexican context. Global Media and Communication, 15(1), 103-119.

Samuelsson, L. K (2 September 2019). Succésommar för Aftonbladet. Aftonbladet. https://www.aftonbladet.se/nyheter/kolumnister/a/kJbggB/succesommar-foraftonbladet. 21 July 2020.

Santesson, P. (14 September 2015). Vem Vågar Prata om Sina Åsikter?. Demoskop. https://web.archive.org/web/20190523175147/https://demoskop.se/vemvagar-prata/. 20 July 2020.

Schemer, C., Wirth, W. and Matthes, J. (2012). Value resonance and value framing effects on voting intentions in direct-democratic campaigns. American Behavioural Scientist, 56(3). 334-352.

Scollon, S. (2003). Body idiom in platform events: Media representation and the hegemony of the vicarious conversation. Social Semiotics, 13(1), 89-102.

Simons, G. (2019). The anatomy of a moral panic: Western mainstream media's Russia scapegoat. Changing Societies and Personalities, 3(3), 189-206.

Skoglund, K. (5 June 2018). Efter krissiffrorna: 54 KD-politiker vill se Adaktusson som partiledare. Expressen. https://www.expressen.se/nyheter/val-2018/efterkrissiffrorna-54-kd-politiker-vill-se-adaktusson-som-partiledare/. 24 July 2020.

(14 June 2018). Svaret-efter Hanif Balis utspel om SD-samarbete. Expressen. https://www.expressen.se/nyheter/val-2018/partisekreterarenssvar-efter-balis-utspel/. 24 July 2020.

Skovsgaard, M. (2014). A tabloid in mind? Professional values and organisational pressures as explanations of tabloid journalism. Media, Culture \& Society, 36(2), 200-218.

Strömbäck, J. and Dimitirova, D. V. (2006). Political and media systems matter: A comparison of election news coverage in Sweden and the United States. International Journal of Press/Politics, 11(4), 131-147.

(2011). Mediatization and media interventionism: A comparative analysis of Sweden and the United States. International Journal of Press/Politics, 16(1), 30-49.

Strömbäck, J. and Nord, L. W. (2006). Do politicians lead the tango? A study of the relationship between Swedish journalists and their political sources in the context of election campaigns. European Journal of Communication, 21(2), 147164.

Strömbäck, J. and Shehata, A. (2007). Structural biases in British and Swedish election news coverage. Journalism Studies, 8(5), 798-812.

Strömbäck, J. and van Aelst, P. (2010). Exploring some antecedents of the media's framing of election news: A comparison of Swedish and Belgian election news. International Journal of Press/Politics, 15(1), 41-59. 
Swedin, D. (21 June 2018). SD:s extremism blir allt tydligare. Aftonbladet. https:// www.aftonbladet.se/ledare/a/a2oG74/sds-extremism-blir-allt-tydligare. 23 July 2020.

Swedish Radio (28 June 2019). Krönikör Katarina Barrling: Om ett Totalitärt Samtalsklimat. https://sverigesradio.se/sida/artikel.aspx?programid=438\&artikel=7253386. 21 July 2020.

TT (15 September 2018). Rekordmånga överklaganden efter valet. Aftonbladet. https://www.aftonbladet.se/nyheter/a/gPnJya/rekordmanga-overklagandenefter-valet. 23 July 2020.

(4 June 2018). Löfven: "Ryssland är det största hotet". Aftonbladet. https://www.aftonbladet.se/nyheter/a/m6wl61/lofven-ryssland-ar-det-storstahotet. 23 July 2020.

Viklund, J. (2015). Vid Politiska Debattens Gräns: Attityd, hegemoni och frågan om volymer i den Svenska invandringsdebatten (At the boundary of the political debate: Attitude, hegemony and the question of volumes in The Swedish immigration debate). A. Sigrell, A. and S. Qvarnström, (eds.) Retorik och Lärande: Kunskap - Bildning - Ansvar (Rhetoric and Learning: Knowledge - Education Learning), Studia Rhetorica Lundensia, vol.1, (211-230). Lund: Lund University.

Walter, D. and Ophir, Y. (2019). News frame analysis: An inductive mixed-method computational approach. Communication Methods and Measures, 13(4), 248-266.

Ethics committee approval: There is no need for ethics committee approval.

Conflict of interest: There are no conflicts of interest to declare.

Financial support: No funding was received for this study.

Etik Kurul Onayı: Etik kurul onayına ihtiyaç bulunmamaktadır.

Çıkar çatışması: Çıkar çatışması bulunmamaktadır.

Finansal destek: Finansal destek bulunmamaktadır.

34 | ETKíleşim |Yıl 4|Sayı 8|Ekim 2021 
ETKILEŞiM 35 